WMJ (Warmadewa Medical Journal), Vol. 6 No. 1 Mei 2021, Hal. 1-6

\title{
Accuracy of STRONGKids to Identify Risk of Children Malnu- trition in Sanjiwani General Hospital Gianyar, Bali
}

\author{
Dewa Ngakan Putu Yogi Astika ${ }^{1}$, Putu Triyasa ${ }^{2}$, Rima Kusuma Ningrum \\ ${ }^{1}$ Medical Education Program, Faculty of Medicine and Health Science, Warmadewa University, Denpasar \\ ${ }^{2}$ Departement of Pediatric, Sanjiwani General Hospital Gianyar \\ ${ }^{3}$ Departement of Medical Education, Faculty of Medicine and Health Science, Warmadewa University, \\ Denpasar \\ Email $^{\text {: }}$ astika.yogi@yahoo.com
}

\begin{abstract}
Malnutrition in the hospital is a condition that needs to be watched out for because it affects the length of stay and healing process of hospitalized patients. Until now, the prevalence of malnutrition in the hospital is still high in both adult and pediatric patients. Malnutrition screening is required while the patient will be hospitalized. It is necessary to research the accuracy of STRONGKids (Screening tools for risk on nutritional status and growth) as a malnutrition screening in pediatric patients in hospitals, especially at Sanjiwani General Hospital Gianyar percentage of malnutrition in hospitals at Sanjiwani Gianyar Hospital so that they receive early treatment. The purpose of this study was to determine the accuracy of STRONGKids as a screening test for malnutrition in the hospital for children at Sanjiwani General Hospital Gianyar. This research uses a design cross-sectional by the diagnostic test method. Data taken from medical records. Data collection method with consecutive sampling. The number of samples is 40 subjects. The inclusion criteria were children aged one month - 18 years and hospitalized at Sanjiwani Gianyar Hospital. The exclusion criteria were incomplete medical record data, and subjects were categorized as obese or obese on the medical record. The data analysis technique used the SPSS computer program. STRONGKids data are presented in $2 \times 2$ table form Chi-square. The results obtained were the percentage of hospital malnutrition of 9.8\%. STRONGKids with a cutoff value of 1 had a sensitivity of $100 \%$ and a specificity of $35.1 \%$. So, the STRONGKids score has fairly high sensitivity, so that the use of the STRONGKids score in combination with anthropometric measurements can be used to detect malnutrition in hospitals.
\end{abstract}

Keywords: sensitivity, STRONGKids, child malnutrition

\section{Abstrak}

\section{[Akurasi Strongkids sebagai Uji Tapis Malnutrisi Rumah Sakit pada Anak di RSUD Sanjiwani Gianyar]}

Malnutrisi di rumah sakit merupakan keadaan yang perlu diwaspadai karena berpengaruh pada perjalanan dan proses penyembuhan penyakit pasien yang dirawat inap. Sampai saat ini prevalensi malnutrisi di rumah sakit masih tinggi baik pada pasien dewasa maupun anak-anak. Skrining malnutrisi diperlukan saat pasien akan dirawat di rumah sakit. Perlu dilakukan penelitian untuk menguji akurasi STRONGKids sebagai uji tapis malnutrisi pada pasien anak di rumah sakit, khususnya di RSUD Sanjiwani Gianyar dan persentase malnutrisi rumah sakit di RSUD Sanjiwani Gianyar sehingga mendapat penanganan lebih dini. Tujuan dari penelitian ini adalah mengetahui akurasi STRONGKids sebagai uji tapis malnutrisi rumah sakit pada anak di RSUD Sanjiwani Gianyar. Penelitian ini menggunakan desain cross sectional dengan metode uji diagnostik. Pengumpulan data dilakukan dengan pencatatan rekam medis. Sampel diambil dengan metode consecutive sampling. Jumlah sampel 40 subyek. Kriteria inklusi adalah anak usia 1 bulan - 18 tahun dan dirawat inap di RSUD Sanjiwani Gianyar. Kriteria eksklusi adalah data rekam medis tidak lengkap dan subyek dikategorikan gemuk atau obesitas pada rekam medis. Teknik analisis data menggunakan program komputer SPSS. Data STRONGKids disajikan dalam bentuk tabel $2 \times 2$ Chi square. Hasil yang didapatkan adalah persentase malnutrisi rumah sakit sebesar 9,8\%. STRONGKids dengan nilai titik potong 1 memiliki sensitivitas 100\% dan spesifisitas 35,1\%. Jadi skor STRONGKids memiliki sensitivitas yang cukup tinggi. Sehingga penggunaan skor STRONGKids dikombinasi dengan pengukuran antropometri dapat dipakai untuk deteksi malnutrisi rumah sakit.

Kata kunci: sensitifitas, STRONGKids, malnutrisi anak. 


\section{INTRODUCTION}

The prevalence of malnutrition in hospitals is still high in both adult and pediatric patients. High rates of malnutrition in the hospital lead to increased length of stay, infection rates, mortality, readmissions, and hospitalization costs ${ }^{(1)}$. Hospital malnutrition is a condition that needs attention because it affects the course and healing of the disease in hospitalized patients $^{(2)}$.

A study on hospital malnutrition was conducted at Sanglah General Hospital and found a $17 \%$ incidence of hospital malnutrition in children. Children treated for more than a week have a 3.7 times greater risk of experiencing hospital malnutrition than children treated for less than a week $^{(3)}$. Another study at Wahidin Sudirohusodo General Hospital Makassar. $8.9 \%$, lower prevalence of hospital malnutrition than Sanglah General Hospital ${ }^{(4)}$.

Nutritional screening aims to identify patients at risk of malnutrition. The screening tool should be short, fast, and adapted to the conditions and agreements in each hospital. Some examples of screening tools include Subjective Global Assessment (SGA), Malnutrition Universal Screening Tools (MUST), Malnutrition Screening Tools (MST), and Nutrition Risk Screening (NRS) 2002. Screening for pediatric patients 1-18 years may be used Pediatric Yorkhill Malnutrition Score (PYMS), Screening Tool for Assessment of Malnutrition (STAMP), or STRONG$\mathrm{Kids}^{(5)}$. In addition, there is a filter test instrument Subjective Global Nutritional Assessment (SGNA) and Simple Pediatric Nutritional Risk Score. Systematic review studies have shown good performance in screening tools for malnutrition in pediatric patients, especially STRONGKids and STAMP. However, further research is needed on this screening tool ${ }^{(6)}$.

Malnutrition screening is required while the patient will be hospitalized. Screening should use a method that is fast, easy, and safe.

This study aims to assess the sensitivity of STRONGKids as a malnutrition screening test in pediatric patients at San- jiwani General Hospital Gianyar.

\section{METHOD}

This study used a cross-sectional design with a diagnostic test method. Data taken from medical records. The diagnostic test method was used to assess the sensitivity and specificity of STRONGKids. The target population is all children hospitalized at Sanjiwani General Hospital Gianyar. The affordable population is children hospitalized at Sanjiwani General Hospital Gianyar from November 2018 - January 2019. Data were collected using consecutive sampling. Every patient who entered and met the inclusion criteria and complete medical record data was included in the analysis. The sample size required in this study was $40 \mathrm{sub}-$ jects, $\mathrm{P}=$ the proportion of hospital malnutrition assumptions with a confidence interval $=95 \%=1.96 . \mathrm{d}=$ precision $(5 \%$ or $0.05)$.

Inclusion criteria:

1. Children aged one month - 18 years.

2. Being hospitalized at Sanjiwani General Hospital Gianyar.

Exclusion criteria:

1. Incomplete medical records.

2. Subjects were categorized as obese or obese in medical history.

\section{Operational Definition;}

STRONGKids Score Determined based on filling in the STRONGKids questionnaire used at Sanjiwani General Hospital Gianyar by nutrition officers. The question in the questionnaire is, First, are there any diseases or conditions that put the patient at risk of malnutrition, or is the patient planning major surgery? (if yes, score 2). Second, based on clinical assessment, is the patient malnourished/poor? (if yes, score 1). Third, are there any of the following conditions? Diarrhea $\geq 5$ times/day or vomiting $>3$ times/day, reduced food intake over the last few days, receive nutritional intervention, unable to consume adequate nutrition due to pain (if yes, score 1). Fourth, has there been any weight loss (for infants $<1$ year: weight not increased) dur- 


\section{WMJ (Warmadewa Medical Journal), Vol. 6 No. 1, Mei 2021, Hal. 3}

ing the last few months? (if yes, score 1). The results are categorized into; 1. Low risk (score 0); 2. Moderate risk (score 1-3); 3 . High risk (score 4-5). The cutoff point value of the STRONGKids score was determined using the ROC curve. After being analyzed, the cutoff points for the STRONGKids score according to this study is 1 . The cutoff point value of 1 means that subjects who score below one are categorized as negative or not at risk of malnutrition, and scores of 1 and above are categorized as positive or at risk of malnutrition.

Nutritional status in this case malnutrition in the hospital used WHO Weight for Height (WFH) <-2SD and CDC 2000 if less than the 50th percentile Nominal; Normal and Malnutrition. Data collection was carried out by recording medical records. The data taken were medical record number, name, gender, age, anthropometric measurements, and STRONGKids scores. Medical record data were collected using anthropometric measurement techniques and interviews to fill out the STRONGKids questionnaire. Measurements taken include measurements of body weight and height.

The data analysis presented in descriptive form is for the prevalence of hospital malnutrition and analytical for applying STRONGKids. The data analysis technique used the Statistical Package for the Social Sciences (SPSS) computer program in table form $2 \times 2$ Chi-square.

\section{RESULT}

The data collected were 56 records. The complete medical record data and fulfilling the inclusion criteria were 41 medical records. So, 41 samples were successfully collected. The characteristic of the sample shown in table 1.

Table 1. Characteristics of subjects

\begin{tabular}{|c|c|c|c|}
\hline \multicolumn{3}{|l|}{ Characteristic } & \multirow{2}{*}{$\begin{array}{l}\mathrm{N}=41 \\
26(63.4 \%)\end{array}$} \\
\hline Gender & Male & & \\
\hline & Female & & $15(36.6 \%)$ \\
\hline \multirow[t]{2}{*}{ Age } & $0-5$ year & & $23(56.1 \%)$ \\
\hline & $6-18$ year & & $18(43.9 \%)$ \\
\hline Nutrition status & WHO (0-5 year) & CDC (6-18 year) & \\
\hline Normal & $23(100 \%)$ & $14(77.8 \%)$ & $37(90.2 \%)$ \\
\hline Malnutrition & $0(0 \%)$ & $4(22.2 \%)$ & $4(9.8 \%)$ \\
\hline \multicolumn{4}{|l|}{ STRONGKids score } \\
\hline Low risk 0 & & & $13(31.7 \%)$ \\
\hline Moderate risk 1 -3 & & & $28(68.3 \%)$ \\
\hline High risk $4-5$ & & & $0(0 \%)$ \\
\hline
\end{tabular}

Male subjects were more than women with a difference of 11 people. Subjects aged 0-5 years were more numerous than those aged 6-18 years with a difference of 5 people.

WFH categories included according to the criteria of this study were -2SD to + 2SD in the normal category and below that included in the malnutrition category for WHO criteria. This category is used in sub- jects aged 0-5 years. The results obtained were all normal subjects, and none were malnourished.

WFH category with the CDC 2000 criteria in the 50th percentile and above were included in the normal category except for those in the written record of being obese or obese. Below the 50th percentile is categorized as deficient. This category is used in subjects aged 6-18 years. The re- 


\section{WMJ (Warmadewa Medical Journal), Vol. 6 No. 1, Mei 2021, Hal. 4}

sults obtained were normal patients more than malnourished with a difference of 10 subjects.

The STRONGKids score result is based on a questionnaire recorded in the medical record. The result is shown in table 2. Subjects who obtained a STRONGKids
1 score had the highest number of 24 subjects, while the second one with 0 was 13 subjects. No subject got a score of 4 or 5 . Referring to cutoff point 1, the STRONGKids score was positive or at risk of malnutrition for 28 subjects and negative or not at risk of malnutrition for 13 subjects.

Table 2. Characteristic of malnutrition

\begin{tabular}{lll}
\hline Characteristics of malnutrition & $\mathrm{N}=41$ & Malnutrition \\
\hline Age & 23 & $0(0 \%)$ \\
$0-5$ years & 18 & $4(22.2 \%)$ \\
6-18 years & & \\
Gender & 26 & $3(11.5 \%)$ \\
Male & 15 & $1(6.7 \%)$ \\
Women &
\end{tabular}

All malnourished subjects were 6-18 years old. Of the four malnourished subjects, male subjects experienced more malnutrition than female subjects.

\section{Sensitivity and Specificity Analysis of STRONGKids as Hospital Screening Test for Malnutrition in Children}

Before getting the sensitivity and specificity results, the cutoff point value of the STRONGKids score was determined using the ROC curve. After being analyzed, the cutoff points for the STRONGKids score according to this study is 1 . The cutoff point value of 1 means that subjects who score below one are categorized as negative or not at risk of malnutrition, and scores of 1 and above are categorized as positive or at risk of malnutrition. After determining the cutoff point, the data tabulation was carried out using a $2 \times 2$ table chisquare. The results of data tabulation are presented in table 3 .

Table 3. STRONGKids score

\begin{tabular}{|c|c|c|c|}
\hline \multicolumn{4}{|c|}{ WHO and CDC nutritional status } \\
\hline STRONGkids score & Malnutrition & Normal & Total \\
\hline Positive & 4 & 24 & 28 \\
\hline Negative & 0 & 13 & 13 \\
\hline Total & 4 & 37 & 41 \\
\hline
\end{tabular}

After analyzing the sensitivity and specificity according to the formula, the results showed that the STRONGKids sensitivity was $100 \%$, and the specificity was $35.1 \%$. The sensitivity of STRONGKids was very high, while the specificity was quite low. The positive predictive value is $14.2 \%$, the negative predictive value is $100 \%$, the false positive is $64.9 \%$, and the false negative is $0 \%$. Positive Likelihood
Ratio (LR +) obtained 1.54, which means very low. A good LR + value is 10 . The negative likelihood ratio (LR-) is 0 , which means very good. Due to the very high sensitivity of STRONGKids, this indicates that STRONGKids can be used as a screening test because they function as a screen that can capture as many people as possible who are likely to get sick. 


\section{DISCUSSION}

Acute malnutrition was described by WFH category using WHO or CDC criteria 2000. In this study, the WHO criteria were used for subjects aged 0-5 years, and the CDC 2000 criteria were used for subjects aged 6-18 years; this was done according to records on medical records. WHO WFH scores <-2SD and CDC 2000 less than the 50th percentile are categorized as acute malnutrition. The results obtained were 37 normal subjects and four malnourished subjects, so that the malnourished subjects were 9.8\%. The STRONGKids score is divided into three categories, namely mild, moderate and severe risk. A total score of 0 is categorized as mild risk, a total score of 1-3 is categorized as moderate risk, and a total score of 4-5 is categorized as severe risk. In this study, 13 subjects with mild risk and 28 subjects with moderate risk were found. Nobody is at serious risk.

Research at Sanglah General Hospital showed that $17 \%$ of the subjects met the hospital malnutrition criteria. The incidence is more in women than men. The age group under one year has the highest number. The criteria used were weight loss during treatment $\geq 2 \%$ in a week or $\geq 5 \%$ in a month or $\geq 10 \%$ in 6 months.' ${ }^{(3)}$.

Research at Wahidin Sudirohusodo General Hospital Makassar shows the prevalence of hospital malnutrition is equal to $8.9 \%$, lower than the research at Sanglah General Hospital. The prevalence of hospital malnutrition in girls is higher than in boys. Hospital malnutrition is most common at 25-36 months of age. Length of stay with a background of chronic disease and multiple diagnoses is still a risk factor for hospital-acquired malnutrition 1.2 times greater than children treated for less than a week $^{(4)}$.

In this study, the percentage of malnutrition based on anthropometric measurements was $9.8 \%$. This percentage is close to Juliaty's research in 2013. The difference with other studies is that this study obtained the most frequent age group at 6-18 years, and the most frequent sex was male. This may be due to different measurement crite- ria for malnutrition or the number of samples available.

In this study, the cut point used for the STRONGKids score was 1 , so a score of 1 and above would be considered a positive test, and a score below one would be considered a negative test. Based on the intersection point, $2 \times 2$ data tabulation was performed chi-square obtained a sensitivity of $100 \%$ and a specificity of $35.1 \%$. This shows that STRONGKids has a high sensitivity for malnutrition screening tests.

The study of the validity of the malnutrition filter test was carried out to assess the sensitivity and specificity of three filter test kits, namely PYMS, STAMP, and STRONGKids, showing the sensitivity of STRONGKids 100 and the specificity of STRONGKids $7,7^{(7)}$. The study using the STRONGKids questionnaire was conducted at Cipto Mangunkusumo Hospital, obtained a sensitivity of $60 \%$ and a specificity of $91 \%$ with a cutoff value of 4 . The criteria for malnutrition in the hospital used were a reduction in body weight of more than or equal to $2 \%$ of the original body weight within the one-week treatment peri$\operatorname{od}^{(8)}$.

Maciel's research et al. year 2018 regarding the validation of STRONGKids to get sensitivity results $84.8 \%$, specificity $26.7 \%$, positive predictive value $49.8 \%$, and negative predictive value $67.2 \%$, when patients at nutritional risk were identified by anthropometry ${ }^{(9)}$.

Based on Wonoputri research in 2014 as well as research by Widjaja \& Hafifah in 2012 and Maciel et al. In 2018, the sensitivity of STRONGKids in this study was the same as the Wonoputri study in 2014, but the specificity was different. This is possible because the research concept and data analysis methods are slightly different, or the number of samples is different.

Teixeira \& Viana in 2016 conducted a literature study on a malnutrition filter test kit. STRONGkids are reported to show high sensitivity, a lower percentage of specificity, and ease of use in clinical practice ${ }^{(6)}$. Many studies on the accuracy of STRONGKids have obtained greater sensi- 
tivity than specificity. This is in accordance with STRONGKids, which functions as a filter test tool and not as a diagnostic tool.

Beser's research in 2018 concluded that researchers recommend that every child who is hospitalized for any reason, suffering from illness or chronic disease, should be evaluated by measuring body weight per length or height along with measuring one of the filter test kits (PYMS or STRONGKids). Researchers believe that using only a screening test without measuring body weight for length or height could ignore some patients who are at risk of malnutrition $^{(10)}$.

Each study may have limitations. The limitations of this study are the use of more than one gold standards so that malnutrition status bias may occur. The determination of the gold standard was chosen based on suitability with the theory and conditions at the research location. The limitation of this research furthermore is the small sample size.

\section{CONCLUSION}

This study found that the percentage of malnutrition in children at Sanjiwani General Hospital Gianyar as much as 9.8\% based on WHO and CDC 2000 weight loss criteria. STRONGKids have a high sensitivity to be used as a screening test for malnutrition in hospitals at Sanjiwani General Hospital Gianyar.

\section{ACKNOWLEDGMENT}

We want to thank all who had provided any support for Sanjiwani General Hospital Gianyar medical staff to provide us to doing research. Special thanks and gratitude to dr. I Ketut Tangking Widarsa, $\mathrm{MPH}$, for the feedback and guidance during this study.

\section{REFERENCE}

1. Subagio HW, Puruhita N, Kern A. Problema Malnutrisi di Rumah Sakit. Medica Hosp. 2016;3(3):143-6.
2. Nasar S, Susanto J, Lestari E, Djais J, Prawitasari T. Malnutrisi di Rumah Sakit, Buku Ajar Nutrisi Pediatrik dan Penyakit Metabolik. Jakarta; 2014.

3. Sidiartha IGL. Insidens Malnutrisi Rawat Inap pada Anak Balita di Rumah Sakit Umum Pusat Sanglah Denpasar. Sari Pediatr. 2016;9 (6):381.

4. Juliaty A. Malnutrisi Rumah Sakit Pada Bangsal Anak Rumah Sakit Dr. Wahidin Sudirohusodo Makassar Aidah Juliaty. Sari Pediatr. 2016;15 (2):65.

5. Menteri Kesehatan Republik Indonesia. Peraturan Menteri Kesehatan Republik Indonesia Nomor 78 Tahun 2013 Tentang Pedoman Pelayanan Gizi Rumah Sakit. 2013;

6. Teixeira AF, Viana KDAL. Nutritional screening in hospitalized pediatric patients: a systematic review. $\mathrm{J}$ Pediatr (Versão em Port. 2016;92 (4):343-52.

7. Wonoputri N, Djais T.B J, Rosalina I. Validity of Nutritional Screening Tools for Hospitalized Children. Nutr Metab. 2018;2014:217-217.

8. Widjaja IR, Hafifah CN, Sjarif DR, Devaera Y, Yuliarti K. Penggunaan Kuisioner Strong Kids Sebagai Uji Tapis Fakultas Kedokteran Universitas Indonesia. 2012;(20110106):0 22.

9. Maciel JRV, Nakano EY, Carvalho KMB de, Dutra ES. STRONGkids validation: tool accuracy. J Pediatr (Rio J) [Internet]. 2020;96(3):371-8. Available from: https:// doi.org/10.1016/j.jped.2018.12.012

10. Beser OF, Cokugras FC, Erkan T, Kutlu T, Yagci R V., Ertem D, et al. Evaluation of malnutrition development risk in hospitalized children. Nutrition [Internet]. 2018;48:40-7. Available from: https:// doi.org/10.1016/j.nut.2017.10.020 